\title{
The Folklore of "Wali 9" (Islam Spreaders) in East Java as Cultural Identity of Multicultural Community
}

\author{
Arif Budi Wurianto \\ University of Muhammadiyah Malang \\ arifbudiwurianto@gmail.com
}

\begin{abstract}
Wali is a word that refers to the person who spreads Islam in the land of Java around the 13th and 14th centuries. The number of wali in the land of Java is nine, so they are well-known as Wali Sanga or Wali Sembilan. The word wali is an abbreviation of Waliullah (the trusted one or the saint) chosen by God to spread Islam in Java, which Hinduism and Buddhism were the main religions at that time. The Wali Sanga introduced and spread Islam peacefully called "Penetration de Pasifique", which spread Islam calmly. Their spreading method was the syncretization and acculturation of culture. The preserved cultural heritages are tombs, literary arts, music art, and art performance. The tombs of the nine saints in East Java are located Gresik, Surabaya, Lamongan, and Tuban. People in East Java periodically visit the tombs for spiritual pilgrimage. This has both religious and social values, which grow the economy of society around the tombs and tour agents that provide transportation. Thus, the tomb is as a sign of social culture of traditional Islamic society in East Java. Another oral tradition is the literary art, such as tembang Macapat (Macapat songs) and a traditional rhythm that depicts the religious syiar, like Ilir-ilir which gives the lesson of Pillars of Islam and the virtue of time, Dhandhanggula, and Kidung Rumeksa Ing Wengi, which describe the efficacy of Ayat Kursy. The songs now undergo cultural transformation in various forms, thus, bringing significant socio-cultural impact. In the art of music, Javanese gamelan for Karawitan, such as Bonang (derived from Sunan Bonang) which initially as a means of da'wah process of Islam in Java becomes a part of the Javanese cultural identities and economic values. Architectural arts, especially mosques that combine traditional elements, transformation of Hindu influences, and the Middle East, make the mosque in Java Indonesia become characteristic of art in the field of architecture and modern design. Similarly, wayang (puppet) first is a means of propagation of Hindu syncretic method with modification of form, function, and meaning. Wayang now has become the cultural identity of Indonesia, and it is one of the World Heritages launched by UNESCO.
\end{abstract}

Keywords: guardian, spreading Islam in Java, transformative Arts-Culture.

\section{INTRODUCTION}

One of the cultural treasures in Indonesia is folklore. Folklore in Indonesia is highly maintained by the community as one of intangible cultural forms that can be one of the patrons in the life of the community. Folklore can be a source of cultural values. One of the cultural values of society is the value of cultural identity and multicultural value. One of the folklore that has become a legend and myth in East Java is a story about Wali Sanga. Wali Sanga refers to Islamic propagators or saints in Java in the 14th century. The number of Wali is 9, so they are called Wali Sanga. They are Sunan Ampel, Sunan Giri, Sunan Bonang, Sunan Kalijaga, Sunan Maulana Malik Ibrahim, Sunan Muria, Sunan Kudus, and Sunan Gunung Jati. The tombs of Sunan Ampel, Sunan Giri, Sunan Bonang,, Sunan Maulana Malik Ibrahim are in Surabaya, Gresik, Lamongan, and Tuban.

The existence of Wali Sanga as saints makes them as the source of spiritual culture, such as their tombs, literary arts, and mythical legacy. Therefore, folklore of Wali-9 in this research focuses on the following explanations: (1) literary evidence, (2) the oral tradition, and (3) cultural identity of multicultural community.

In Babad Tanah Jawi (Sunan Ampel Denta), Sunan Ampel Denta is the first wali who lives in Java, but Sunan Giri's authority among the wali gives a greater recognition. Sunan Kalijaga is very important in building the foundations of the Islamic Kingdom of Mataram, while Sunan Kudus is the defender of Demak Kingdom. It is clear from this chronicle (story), and later it has elaborated on the role of Wali Sanga to represent and embody the Sufi important traditions that form the basis of Islamic tradition in Java (J. Fox, James Ed. 1998. : 18).

\section{METHOD}

This research uses qualitative approach to describe and explain the meanings found in the study descriptively. This research is a research which focuses on folklore, people's songs, and oral tradition in the form of relics of artifacts that store spoken told by the people. The data are folklore data. Data analysis uses content analysis and meaning.

\section{RESULT}

The literary evidence found and believed to be a relic of the saints is oral literature. Oral literature in the form of poems in the form of syiir and tembang. Most of these literary heritages are claimed by the relics of Sunan 
Kalijaga. Although the artifacts of Sunan Kalijaga's tomb are in Central Java, but the existence of Sunan Kalijaga when he propagated Islam exists in East Java, especially the northern coast.

Literary evidence of the legacy of the wali in developing Islam is in Javanese songs known by the people. The songs are in kind of grouped-rhymed poetry in accordance named Pupuh, which are as (1) Maskumambang (in the womb) referring to Javanese language kumambang, which means floating. It describes a baby floating in his mother's womb. The characteristics of this song is about sadness and crying; (2) Mijil (born) referring to mijil, mbrojol or mencolot, which means coming into the world. It describes the birth of a baby. The characteristics of this song is full of affection. (3) Sinom (young) or kanoman in Javanese language, which means 'young'. It describes a beautiful youth story, which is full of hope and wish, and seeking knowledge to make it happen. The characteristics of this song is about happiness; (4) Kinanthi or kanthi (Javanese language), which means guidance or being guided to reach the future. It describes the period in which humans form their selfidentity and walk to ideal path; (5) Asmarandana (romance) or tresna in Javanese language, which means love or romance. It describes the period in which humans are full of romance drowning in a sea of love. The characteristics of this song is being in love; (6) Gambuh (match), in Javanese language is jumbuh or sarujuk, which means being matched with. It describes commitment and readiness to get married. The characteristics of this song is about self-introduction; (7) Dhandhanggula (happy), or kasembadan in Javanese language, which means pleasure. It describes the success of having a happy family and accomplishing goals. The characteristics of this song is very romantic; (8) Durma (generous), in Javanese language is darma or weweh, which means being generous or willing to give charity. It describes a gratitude to God who has given all the best. The characteristics of this song is full of spirit; (9) Pangkur (away from lust) or mungkur Javanese language, which means to stay away from. It describes a man who gets rid of his wrath, a negative passion that exists in his soul. The characteristics of this song is about being firm; (10) Megatruh (death) or megat roh in Javanese language, which means the coming out of spirit. It describes the release of a human spirit or death. The characteristics of this song is full of sadness; and (11) Pocung (wrapped in white mori) or pocong in Javanese language, which means being wrapped. It describes the human's death starting from being bathed, prayed, and buried. The characteristics of this song is sembrana, gecul, ora ana greget saut.

This Javanese literature also developes into Madura, West Java, and Lombok in line with its function as a medium for spreading Islam. This literary evidence suggests mixed cultural traits or syncretism and acculturalism. As an example in the song Dhandhanggula Kidung Rumeksa ing Wengi, it is actually an Arabic prayer composition taken from the Qur'an verse Kursy, but it is manifested in the literature of Javanese song. Another literary evidence is the oral literature of a very famous legend Sunan Kalijaga, known as Lokajaya Berandal Story. It presents the struggle of Raden Sahid, a son of Tuban Regent, who later devoted himself and studied to Sunan Bonang (Syech Maulana Malik Ibrahim) and became one of the Wali Sanga named Sunan Kalijaga. It can be concluded that the evidence of literature based on the story of the Wali in East Java for centuries is still believed and made a sense of strengthening the traditional identity of Islam and its historic elements. Although the beginning of this literary evidence is Islamic, it is widely appreciated and used by different societies. This is a multicultural concept in East Java.

In this study, the oral tradition studied is the motif and theme that develop in East Java. Oral tradition known widely in East Java usually contains educational values and is able to become a moral force for the growth of multiculturalism in East Java.

Due to many traditions about the wali, there is a divergence of views about the details of their lives. Some stories about the wali are exemplary story about the message of Sufi teaching to the worthlessness of wealth, and power and status for their own sake compared with the value of the wali whose whole life is dedicated to the God's will. Some of the best known episodes from the life of the wali illustrate these teachings. A good example is the story of Sunan Kalijaga converted by Sunan Bonang.

This story is told briefly in Babad Tanah Jawi. It tells a young man, Raden Sahid, gambles and robs travelers a the forest called Jati Sekar in Lasem. In this forest, he meets Sunan Bonang who tells him it would be better to rob the person who wears dark blue dress, and he will pass through the forest soon. This person turns out to be Sunan Bonang who convinces Raden Sahid to leave his way and to meditate in the forest instead. After two years Raden Sahid meditates at the bank of Jaga River in Cirebon, he changes his name to Sunan Kalijaga, which is adopted as the brother-in law of Sunan Gunung Jati. There are various different popular retold stories of these episodes. For example, Raden Sahid tries to steal Sunan's walking stick because he thinks that it is covered in gold, and he rips up a piece of grass. The walking stick, however, turns out to be a wooden stick, which Raden Sahid offers to return. But to his consternation, the Sunan mourns the loss of single blade of grass. He tells Raden Sahid that if he wants gold, all he has to do is to climb a nearby Aren or Palm tree, which bears golden fruit. Raden Sahid climbs the tree and picks the golden fruit. When he reaches the ground, the golden fruit becomes ordinary fruit. It convinces Raden Sahid to change his life. He sets himself upon the path to be a great wali, Sunan Kalijaga.

The religious social impact on traditional Islamic societies today is that the Wali Sannga's tombs are always used as pilgrimage destinations, called ziarah wali. This phenomenon affects the growth of the sectors of economy, tourism, and social solidarity. The tombs of Wali Sanga are all important sites where visitors may come to pray, a popular act of religious piety. There are also traditional Muslim students from a pesantren reciting the Quran at the tomb of Wali Sanga's tombs. 
The existence of the tombs of Wali Sanga, folklore and oral tradition that flourish, as well as the growing popularity of pilgrimage activities to the tombs of the Wali, indicate the existence of a growing cultural identity in Java, especially East Java. This cultural identity is very important because the identity becomes an indicator of cultural support and cultural values that are able to become social power. East Java is a province which has a various population or multicultural community. The existence of Wali is believed to be the beginning of the spread of Islam in Indonesia, especially in Java, which can be interpreted as a cultural unity and symbol of tolerance.

Aspects of cultural identity and description of the multicultural community also illustrate the growth of Islamic empires (Kasultanan) in Java and the growth of trading cities, such as Lasem, Tuban, Gresik, and Surabaya, and also the number of pesantren as Islamic institutions in East Java. The multicultural community awakens. The unity of society is built through the narrative of the nation in which the stories of Wali Sanga, their image as saints, symbols, and rituals on their tombs present the common meaning of community collectivity.

Cultural identity is the identification of the representation of shared experiences and history through stories, literature, culture, and media. The national narrative emphasizes the nation's tradition and constancy as something that exists in the nature of things at the same time as the basic myth of collective origins. In turn, the national narrative assumes and produces a link between national identity and cultural identity (in this case, the cultural tradition of the people). It assumes that the social cohesiveness that forms the cultural identity of the survival cultural identity of each ethnic is very important as a filter in blocking the impact of globalization.

\section{CONCLUSION}

The existence of Wali Sanga, their sacred tombs, and the worship by the society is closely related to a legend and mythical legacy about Wali Sanga as an oral tradition, both folklore and folksongs. Wali Sanga in East Java remain trusted for centuries, and strengthen the identity of Islam as traditional elements of history. Although the beginning of this literary evidence is based on Islam, it is widely appreciated and used by different societies. This is a multicultural concept in East Java.

The religious social impact on traditional Islamic societies today is that the Wali Sanga's tombs are always used as pilgrimage destinations, called ziarah wali. This condition implies the growth of the sectors of populist economy, tourism, and social solidarity.

The unity of society is built through the narrative of the nation in which the stories of Wali Sanga as the image of the saints, symbols, and rituals on their tombs present the common meaning of "community collectivity. Cultural identity is the identification of the representation of shared experiences and history through stories, literature, culture and media.

\section{BIBLIOGRAPHY}

[1] Dananjaya, James. 2002. Folklore Indonesia. Jakarta: Grafiti.

[2] Dinas Kebudayaan dan Pariwisata Jawa Timur.1995. Banjaran Demak, Pajang dan Mataram Baru.

[3] Fox, James. (ed). 1998. Religion and Ritual. Singapore: Didier Millet.

[4] Hadi, WM, Abul. 2016. Cakrawala Budaya Isla. Yogyakarta: IRCiSoD.

[5] Sedyawati, Edi (Ed). 2001. Sastra Jawa. Jakarta: Balai Pustaka

[6] Tanojo, R. tanpa tahun. Walisana. Solo: Sadubudi. 